\title{
Ecofeminism and Enviromental Protection: A Legal Perspective
}

\author{
Budi Hermawan Bangun \\ Faculty of Law, Universitas Tanjungpura-Indonesia \\ budi.h.bangun79@gmail.com
}

\begin{abstract}
Women are very important figures to ensure sustainable development. This paper discusses the role of women in environmental protection from the perspective of eco-feminism and law. This research is a non-doctrinal legal research with a socio-legal approach. The data used are secondary data obtained through literature studies, then the data that has been obtained is analyzed qualitatively. It is learnt from the discussion that eco-feminism as a thought that criticizes the dominance of patriarchy over control of environmental management and has succeeded in encouraging environmental protection movements carried out by women in various countries. Women are key actors in using, managing and protecting natural resources. Environmental preservation is closely related to the role of women. From a legal perspective, eco-feminism is an effort by the people to seek justice as the main goal of law and ensure the principle of equality before the law in monitoring, protecting and enjoying the benefits of environmental sustainability.
\end{abstract}

Keywords: Ecofeminism, Environmental Protection, Legal Perspective.

\section{A. Introduction}

The environment is created as a part of human life that can be used and preserved. As one unit, humans and the environment coexist and interact with each other. Human interaction with the environment is 
a natural process. This is because humans need the carrying capacity of environmental elements for their survival.

Humans and the environment are interdependent relationships, because humans are very dependent on the environment and vice versa, the environment also depends on human activities. ${ }^{1}$ The objective of environmental policy is to realize the management and utilization of natural resources and the environment in a sustainable and equitable manner in line with the improvement of community welfare in a better and healthier environment.

Talking about the environment cannot be separated from the role of women. Currently, women make up almost half of the world's population. ${ }^{2}$ but as a result of the patriarchal culture that dominates cultures in almost all parts of the world, women are often left in the decision-making process, including to be able to access their life sources. It would be better to use the world's female population to increase economic growth, reduce poverty, improve social welfare, and help ensure sustainable development in all countries. ${ }^{3}$ In fact, there are not many women's roles in preserving the environment. The space for deeper involvement is also deemed inadequate. Women are often not involved in most policies and controls over the natural resources that support them.

The issue of environmental preservation is closely related to the role of women. Women are very important figures to ensure sustainable development. Women are key actors in using, managing and protecting natural resources. ${ }^{4}$ Women's activities cannot be separated

1 Iskandar, Ekologi Manusia dan Pembangunan Berkelanjutan (Human Ecology and Sustainable Developmet), Bandung: Program Studi Magister Ilmu Lingkungan Universitas Padjajaran, 2009, p. 1.

2 Ritchie \& Roger, 2019, Gender Ratio, https: / / ourworldindata.org/genderratio\#what-share-of-the-population-is-male-and-female, accesed in August12, 2020.

3 OECD, 2008, Gender and Sustainable Development: Maximising The Economic, Social and Environment Role of Women, https://www.oecd.org/ social/40881538.pdf, accesed in August12, 2020.

4 Haider, "Women, Poverty and the Environment", in Rahman, et al. (eds.), Environment and Development in Bangladesh, Dhaka: University Press Ltd, 1994, p. 279. 
from the environment which makes women actually very attached to the environment. This is related to several reasons: ${ }^{5}$ first, physiologically women are involved for a longer period of time with the species of life in which women are caring for the human future. Second, the position of women in the domestic sphere is where babies are transformed into cultural creatures. Third, the psychology of women as mothers produces a more relational, concrete way of thinking compared to men. Fourth, women who are responsible for the domestic area have a lot to do in reducing the amount of waste by implementing the $4 \mathrm{R}$ (reduce, reuse, recycle, and restore). program

Women also have a very vital role in environmental management and development. Active participation and full dedication are the most essential things in sustainable development. In addition, women as mothers are the first and foremost educational media for their children. Through mothers, education and awareness about caring for the environment can be instilled in children from an early age. From the application of an environmentally friendly lifestyle in a family, children will get used to protecting their environment. If these habits and awareness are rooted in children, in the future there will be a generation who cares about the environment. It can be said that women have a strategic role to protect and preserve the environment, to monitor environmental damage and pollution and can become "agents of change" and policy makers in developing a gender responsive environment.

The relation and involvement of women has actually succeeded in encouraging the emergence of social movements for environmental conservation efforts, which then gave birth to an alternative perspective in criticizing the relationship between humans and their natural surroundings, namely ecofeminism. Ecofeminism assumes a relationship or linkage between human domination of nature and the women exploitation by patriarchs. ${ }^{6}$

This article will discuss the movement of ecofeminism in envi-

5 Susilo, Sosiologi Lingkungan (Enviromental Sociology), Jakarta: Raja GrafindoPersada, 2008, p. 120-121.

6 d'Eaubonnein Tong, Feminist Thought, Yogyakarta: Jalasutra, 2010, p. 251. 
ronmental protection from legal perspective. For that, the discussion will begin with the history and development of ecofeminism and continue with ecofeminism and awareness movements for environmental protection and eco-feminism from legal perspective.

\section{B. Result and Discussion}

\section{History and Development of Ecofeminism Thought}

Feminism is a movement concept to oppose the power of the patriarchal system in life. In essence, what feminism strives for is power in any form that suppresses the system so that it favors the rulers themselves. Patriarchal traits are known in the form of prioritizing men in the formation of joint decisions, subordinating women to social structures and leading to unfair pressures and systems. In its development, feminism gave birth to various types of understandings and movements, in accordance with the approaches and specific objects it opposed. One of them is ecofeminism. What ecofeminism strives for is the balance of the relationship between humans and nature in which women as one of the subjects take their roles as reminders and claimants of system injustices.

Ecofeminism was born from the union of terms between ecology and feminism. This union is born from the unity of the same fate, history and characteristics which can be described in a culturallinguistic approach. According to Bourdieu there is the formation of institutions that reproduce gender hierarchies. This makes it easier for humans to carry out a historical analysis of the constancies and transformations of the institution. ${ }^{7}$ Bourdieu further explained that men always dominate the public sphere and the field of power (especially economic power over production). While women are still placed in private spaces (houses, production sites). ${ }^{8}$ In fact, tracing history in ancient times, women were decisive in managing land and

7 Bourdieu, Dominasi Maskulin (Masculinity Dominance), Yogyakarta: Jalasutra, 2010, p. 124.

8 Ibid., p. 132. 
nature aimed at the needs of their families or colonies. ${ }^{9}$

Feminist and ecological movements are movements that criticize the competition, aggression and domination generated by the modern economy and become a movement for liberation. ${ }^{10}$ Both have mutually reinforcing goals, both want to build a view of the world of practice based on patriarchal models and dominations. ${ }^{11}$ The relationship between the ecological destruction of the world today and the strong domination of women as a result of androcentric views and practices. The link between feminism and the environment is historically causal. The philosophers of ecofeminism argue that the basic concept of the dual domination of nature and women is the dualism of values and a hierarchy of values. ${ }^{12}$

The combination between these two movements which later transformed into an eco-feminism movement. This movement was pioneered by Rachel Carson who wrote in her book "The Silent Spring" which was published in 1962.This book has awakened most of mankind to the environment that has been poisoned and polluted by humans themselves, and humans never thought that one day the environment and everything that lived on earth would face the threat of death, which means the death of all human beings on this earth. ${ }^{13}$ The term ecofeminism itself appeared around 1974 in a book

9 Soekarno, Sarinah, Jakarta: Jajasan Pembangunan Djakarta, 1951, p. 90.

10 Wulan, "Ekofeminisme Tranformatif: Alternatif Kritis Mendekonstruksi Relasi Perempuan dan Lingkungan” (Transformative Ecofeminism: Critical Alternative in Deconstructing the Relation of Women and Environment), Soladity: Jurnal Transdisiplin Sosiologi, Komunikasi, dan Ekologi Manusia, Vol. 1, No.1, p. 108.

11 Astuti, "Ekofeminisme dan Peran Perempuan dalam Lingkungan" (Ecofeminism and the Role of Women in Environment), Indonesian Journal of Conservation, Vol. 1, No. 1, p. 51.

12 Maulana \& Supriatna, "Ekofeminisme: Perempuan, Alam, Perlawanan Atas Kuasa Patriarkhi dan Pembangunan Dunia (Wangari Maathai dan Green Belt Movement 1990-2004)" (Ecofeminism: Women, Nature, the Resistance towards Patriarchal Power and World Development), Factum, Vol. 8, No. 2, p. 262.

13 Sale, Revolusi Hijau: Sebuah Tinjauan Historis-Kritis Gerakan Lingkungan Hidup di Amerika Serikat (Green Revolution: A Historical-Critical View to the Environmental Movement in United States), Jakarta: Yayasan Obor Indonesia, 1996, p. 3. 
by Francoise d'Eaubonne entitled "Le Feminismeou la Mori". The book suggests that feminist theory and practice should include ecological practice and ecological solutions and must include a feminist perspective. From here, the ecofeminism movement began to get a place, in 1975 the movement was developed by Ynesta King with ecological specifications, and in 1980 it focused more on the relationship between women and the earth (women and life on earth). ${ }^{14}$

At a theoretical level, ecofeminism originates from the environmental conservation movement that is rife in the West, such as damage to human ecosystems by placing more emphasis on nature (ecology).On a practical level, there are predictions that there are injustices experienced by women in society. Injustice against women in this environment comes first from the notion of injustice committed by humans to other humans or nature. Because women are always associated with nature, conceptually, symbolically and linguistically there are links between feminist and ecological issues. ${ }^{15}$ Ecofeminism combines ecological criticism with gender criticism aimed at western science which is dualistic, tends to be dominated by technology, and is gender blind. Ecofeminists argue that domination over nature is directly related to economic, cultural, psychological factors that create hierarchies, and in practice oppressing the women and exploitating the nature.Characteristics of masculine ideas such as war and violence, discrimination, ethnocentric views, which are facilitated by western technology and science are seen by ecofeminists to be a major threat to the sustainability of nature and the environment. Ecofeminism analyzes environmental problems from criticism of patriarchal culture and offers alternatives that can liberate both women and nature. ${ }^{16}$

Karen Warren argues about ecofeminism, according to her that the ecofeminism movement is not only about criticizing the

14 Fatimah, "Ekofeminisme: Teori dan Gerakan” (Ecofeminism: Theory and Movement), Jurnal Komunikasi dan Penyiaran Islam, Vol. 1, No. 1. p. 10-11.

15 Arivia, Filsafat Berperspektif Feminis (Feminist-Perspective Philosophy), Jakarta: Yayasan Jurnal Perempuan, 2003, p. 144.

16 Ibid., p. 146. 
domination of men and women and nature, but also touching on all aspects. ${ }^{17}$ The existence of ecofeminism is for global development that is built not only on the relationship between women and nature, but more complex, namely for the understanding of women, nature, race, and so on. ${ }^{18}$ For some other ecofeminist, through ecofeminism, the women's movement is an alternative to teach that by rejecting patriarchal capitalism that exploits the environment and by assertively guarantees the giving of equal roles for women to solve environmental problems in the use of natural resources. ${ }^{19}$

Ontologically, ecofeminism views human existence and the entire contents of the cosmos as "something that is related". All the elements in the cosmos cannot exist without being related to one another. ${ }^{20}$ Epistemologically, the placement of femininity principles in the development of knowledge can create a more environmentally friendly, gender-just, non-exploitative and non-reductionist character of science. ${ }^{21}$ Meanwhile, axiologically, the traditions and values that are inherent and championed by women are considered to have a better rank compared to men, so that their values can be adopted for environmental management. ${ }^{22}$

During its development, ecofeminism thought was divided into several schools of thought. The difference in this variant is because the advocates of ecofeminism do not agree on whether the relationship between women and nature is, in essence, biological and psychological, or, in essence, social and cultural. They also disagree on whether women should eliminate, emphasize, or reshape their rela-

17 Ibid., p. 144.

18 Cuomo, Feminism and Ecological Communities: An Ethic of Flourishing, New York: Routledge, 1998, p. 36.

19 Shiva \& Mies, Ecofeminism: Perspektif Gerakan Perempuan dan Lingkungan (Ecofeminism: the Perspective of Women and Environmental Movement), Yogyakarta: IRE Press, 2005, p. 19-20.

20 Suliantoro, "Rekonstruksi Pemikiran Etika Lingkungan Ekofeminisme Sebagai Fondasi Pengelolaan Hutan Lestari” (The Reconstruction on the Thingking of Ecofeminism Environental Ethics as the Foundation of Sustainable Forest Management), Jurnal Bumi Lestari, Vol. 11, No. 1, p. 113.

21 Ibid., p. 114.

22 Ibid., p. 115. 
tionship with nature.

Table 1: Comparison of Ecofeminism School of Thought ${ }^{23}$

\begin{tabular}{|c|c|c|}
\hline $\begin{array}{l}\text { Schools of } \\
\text { Thought }\end{array}$ & $\begin{array}{l}\text { Assumptions on the Relationship be- } \\
\text { tween Women and Nature }\end{array}$ & $\begin{array}{l}\text { Feminism } \\
\text { Roots }\end{array}$ \\
\hline $\begin{array}{l}\text { Natural } \\
\text { Ecofeminism } \\
\text { (Cultural) }\end{array}$ & $\begin{array}{l}\text { Trying to reinforce that the traits associated } \\
\text { with women are not merely the result of } \\
\text { cultural constructs but also the product of } \\
\text { actual biological and psychological experi- } \\
\text { ences. }\end{array}$ & $\begin{array}{l}\text { Cultural } \\
\text { Radicals }\end{array}$ \\
\hline $\begin{array}{l}\text { Spriritual } \\
\text { Ecofeminism }\end{array}$ & $\begin{array}{l}\text { - Seek to strengthen the close relation- } \\
\text { ship between environmental degradation } \\
\text { and the belief that God has given humans } \\
\text { "power" over the earth. } \\
\text { - The relationship between women and } \\
\text { nature benefits more than the relationship } \\
\text { between men and nature. }\end{array}$ & $\begin{array}{l}\text { Cultural } \\
\text { Radicals }\end{array}$ \\
\hline $\begin{array}{l}\text { Social Ecofemi- } \\
\text { nism }\end{array}$ & $\begin{array}{l}\text { - Remove the emphasis on women's rela- } \\
\text { tionships with nature. } \\
\text { - Living things are natural and also cultural. }\end{array}$ & Socialism \\
\hline $\begin{array}{l}\text { Tranformative } \\
\text { Ecofeminism }\end{array}$ & $\begin{array}{l}\text { - Recognizing and explicitly linking all op- } \\
\text { pressive systems. } \\
\text { - Emphasize the diversity of women's expe- } \\
\text { riences, and avoid the search for "women" } \\
\text { and experiences with them. } \\
\text { - Rejects the logic of domination. } \\
\text { - Rethinking what it means to be human, } \\
\text { and courageously reconsider whether } \\
\text { humans should view "consciousness" (and } \\
\text { rationality), not only as differentiating } \\
\text { humans from non-humans, but also making } \\
\text { humans better than non-humans. } \\
\text { - Rely on ethics that emphasize traditional } \\
\text { "feminine" values which tend to intertwine, } \\
\text { connect, and unite people. } \\
\text { - Opinion that science and technology are } \\
\text { only used to maintain the continuity of the } \\
\text { earth. }\end{array}$ & $\begin{array}{l}\text { Transforma- } \\
\text { tive }\end{array}$ \\
\hline
\end{tabular}

Despite there are the differences in the aforementioned views, there is a common vision of eco-feminism thinking that humans

23 Quoted and processed from Wulan, Op.Cit., p. 120. 
are treated first as humans, not as men and women, by prioritizing awareness of the essential meaning of the unity of all things, which will enable humans to identify themselves with all of universe.

\section{Ecofeminism and Environmental Protection Awareness Movement}

One of the advantages of ecofeminism is that it is able to explain the background of environmental damage globally with the subordination of women. Ecofeminism sees social, cultural, and structural problems in the form of very strong dominance in relations between human groups, in this case related to gender and the relationship between humans and the natural environment that causes a lot of suffering for humans. Ecofeminism also illustrates that the energy of feminism has great potential in preserving the environment, preserving the earth. Ecofeminism is able to explain that gender equality ultimately benefits not only women, but all humans..$^{24}$

The simple analogy of ecofeminism is that if the environment is damaged then all humans (both men and women) will get the negative effects of this bad ecosystem and vice versa if the natural environment is well maintained then all humans will feel the benefits as well. ${ }^{25}$

Since the industrial revolution until now, the presence of capitalism has caused development to often ignore and change the position of nature into a commodity with economic value. This makes natural resource management based on the calculation of exchange and added value. The birth of modern capitalism and a set of its components has also affected the ability of women in their productivity to manage life with machines which in multiples are able to coordinate as much as possible and to increase the added value of

24 Gina, 2017, Ekofeminisme: Menyoal Perempuan dan Alam (Ecofeminism: Questioning Women and Nature), https://www.jurnalperempuan.org/blog/ ekofeminisme-menyoal-perempuan-dan-alam, accesed in August 16, 2020.

25 Zega \& Putri. 2014, Relasi Alam dan Perempuan dalam Pemikiran Ekofeminisme Vandana Shiva (the Relation of Nature and Women in the Thingking of Vandana Shiva on Ecofeminism). http:/ / lib.ui.ac.id/naskahringkas/201605/S57107-Devi\%20Christiani\%20Zega, accesed in August 16, 2020. 
production work.

However, in various parts of the world, women's movements can be found in restoring the ecological crisis and defending their sources of life from the greed of capital. In India there was the Chipko Movement (in the 1970s when women in the city of Reni (northern India) agreed to stop deforestation by hugging trees that were going to be cut down by wood cutting machine of large companies supported by the Government of India for commercial purposes. The Chipko Movement is a concrete action undertaken by women and became the starting point for the environmental feminist movement in India as well as popularizing the term ecofeminism, which in the end this movement succeeded in saving 12,000 square kilometers of forest area. ${ }^{26}$

In Kenya, there is the Green Belt Movement pioneered by Wangari Maathai in 1977 which is oriented towards solving the environmental crisis and efforts to improve the image of women. ${ }^{27}$ This movement succeeded in restoring the image of women and even motivating men to join in planting trees for their families and for their children and grandchildren. The Green Belt Movement not only encourages people to plant trees for firewood purposes only or to revive springs, but also advocates for preserving local food sources for food security.In addition, the Green Belt Movement also provides employment opportunities for rural women so that they can get additional income to meet their daily needs and conduct counseling on eradicating malnutrition that is often experienced by rural communities in Kenya. For his efforts, Wangari Maathai was awarded the Nobel Peace Prize in 2004.

Organizations that are founded and run by women in relation to environmental protection awareness are also emerging in a number of countries. In Korea, there is a Salimist who has 10 principles of life based on the historical and spiritual wisdom of Korean women. ${ }^{28}$ In

26 Tong, Op. Cit., p. 386.

27 Scott, 2013, "Peace Profile: Wangari Maathai and the Green Belt Movement”, Peace Review: A Journal of Social Justice, Vol. 25, No. 2.

28 Astuti, Op. Cit., p. 55. 
Venezuela in 1985 established AMIGRANSA (Asociacion de Amigos enDefensa de la Gran Sabana) which has the main objective of defending the Great CanaimaSabana National Park (la Gran SabanaCanaima), followed by GEMA (Grupo de EstudiosMujer y Ambiente) or Women's Study Group and Environment in 1989 with a focus on health and environmental issues in two large squatter shelters in Caracas, the capital of Venezuela, and the condition of women in mining in the Guayana region. ${ }^{29}$ In 1991 also in Venezuela was established AMAVEN (AsociacionVenezolana de MujeryAmbiente) or the Association of Venezuelan Women and the Environment which focuses on improving living standards and obtaining fairer benefits for society, especially lower class women. ${ }^{30}$

In Indonesia, several names of women activists have colored the struggle for environmental protection. In East Nusa Tenggara there is the name Aleta Baun or better known as Mama Aleta. This woman from the Mollo tribe, Timor Tengah Selatan Regency, is the figure behind the rejection of the Mollo indigenous community against the presence of marble mining companies in Fatukoto Village. The struggle against marble mining companies that was carried out in the mountains, which is the customary territory of the Mollo tribe which has caused deforestation, landslides and polluting the river, was started by Mama Aleta in the 1990s along with several other women. This action has made him a target of threats from both corporations and the security apparatus.In 2006, Mama Aleta succeeded in garnering the support of hundreds of members of her indigenous community, especially women who carried out weaving movements at mining sites. The men helped by carrying out childcare activities, cooking and delivering food to the women who continued to weave at the mining site. With this step, Mama Aleta has devised a strategy of peaceful resistance by placing women on the front lines to avoid any possible physical clashes that may occured..$^{31}$ The resistance of Mama

29 Ibid.

30 Ibid.

31 Dalupe, "Dari Hutan ke Politik: Studi Terhadap Ekofeminisme Aleta Baun di Mollo-NTT" (From Forest To Politic: Study on Aleta Baun's Ecofemi- 
Aleta and the indigenous people of Mollo finally succeeded in stopping marble mining activities in 2012, but Mama Aleta is still leading efforts to save the environment by replanting damaged forests and building economic independence for the indigenous people of Mollo.

A similar story happened in Papua, a woman from the Amungme tribe in Timika Regency named YosephaAlomang or Mama Yosepha fighting for community rights against a mega corporation called PT. Freeport Indonesia. The same fate as Mama Aleta, this resistance made her face threats from the security apparatus.Accused of being involved in the Free Papua Organization, Mama Yosepha along with another woman named Yuliana Magal were detained and tortured for approximately one month and were subject to compulsory reporting for five years.Mama Yosepha had also mobilized hundreds of Amungme women to build a massive fireplace at the Timika airport which made the flight stop completely. The women's action was a form of protest against the confiscation of land and vegetable gardens from the Timika community by PT. Freeport Indonesia, which has an interest in building a number of buildings and hotels in the Timika area. ${ }^{32}$ Mama Yosepha's persistence against PT. Freeport Indonesia, including its parent company, Freeport McMoranCooper\& Gold, eventually produced results by winning claims for compensation from the company and several awards such as the Yap Thian Hien Award and the Goldman Environment Prize received by Mama Yosepha.

In Rembang, Central Java, the women of the Kendeng mountain region have shown extraordinary courage in defending springs from the threat of limestone mining and the establishment of a cement factory was pioneered by Gunarti. Gunarti became the first woman to mobilize mothers in her village to protest against limestone mining in her village.Gunarti toured seven villages to meet the women there and tell them why the cement factory had to be protested. The threat of building a cement factory is not only in the village, but

nism in Mollo-East Nusa Tenggara), Jurnal Polinter, Vol. 5, No. 2, p. 41.

32 Astuti, Op. Cit., p. 56. 
also in several areas in Pati Regency. Miners are eyeing limestone in the Kendeng mountains which is the source of livelihood for the surrounding community. The peak of Gunarti's resistance and the Kendeng women was the act of casting their legs opposite the State Palace in April 2016.

Some of the descriptions of women's movements on environmental protection and management above have shown how the mindset, culture and physical and emotional closeness between women and the environment are the level of ecofeminism.

\section{Ecofeminism in Legal Perspective}

Justice is the goal of law because the function of law is to maintain the public interest in society, protect human rights and create justice in living together.

With regard to good environmental management in a proportionate manner, it can maintain stability between rights and obligations when utilizing these natural resources. The role of justice in environmental management is seen when the use of natural resources for economic interests is in line with environmental conservation which is needed to support the quality of human life. Damage to the ecosystem means that it has aborted the rights inherent in everyone that locks down basic rights in the basic law, namely the right to have a good and healthy environment. In Article $28 \mathrm{H}$ Paragraph (1) of the 1945 Constitution of the Republic of Indonesia that, "everyone who has the right to live in physical and mental prosperity, has a place to live, and has a good and healthy living environment...". In the perspective of international law, the protection of these types of rights can be found in the universal declaration of human rights, especially in Article 25 paragraph (1) as well as in the International Covenant on Civil and Political Rights and the International Covenant on Economic, Social and Cultural Rights which guarantees the implementation of rights. this must be done without discrimination.

The environment is a manifestation of the interaction of living things in this cosmic world. Environmental management is carried 
out inefficiently, which is the embryo of disrupting the order of life. Human interaction with the environment is a natural process and is carried out from the time a human is born until he dies..$^{33}$ This applies to all living things so that the environment is one component that must be maintained at all times.

Currently the use of natural resources is dominated by capitalistic economic interests which are often supported by the government on the pretext of national development and public interests. As a result, the legal norms that are born and the realization of law enforcement in the field are not balanced, and even the existing regulations do not accommodate the values of justice holistically.In the perspective of ecofeminism, capitalist and patriarchal policies and practices which in turn produce regulations with a similar style are the cause of environmental damage. Thus the movement carried out by ecofeminism is not just a movement for environmental protection, but is a movement to change a more just social structure.

This can be seen, for example, with the thought of one of the leaders of eco-feminism, namely Vandana Shiva, who offers an ecological concept of social justice as an alternative solution in environmental protection. Ecological social justice regulates the relationship between humans and the entire universe.Nature consists of humans, animals, plants, biotic and abiotic objects, all of which are entitled to fair treatment. In the concept of earth democracy offered by Shiva, every element in nature has a value in itself (intrinsic value), so its existence needs to be respected and respected. ${ }^{34}$ This concept is actually universal and can be found in various cultures. In Indonesia, for example, the awareness to be fair to nature and to others already exists in people's lives and can be found in various local wisdoms throughout the archipelago.

For ecofeminism too, the use of natural resources needs to consider a more gender sensitive sense of justice. Those who get greater

33 Slamet, Kesehatan Lingkungan (Environmental Health), Yogyakarta: Gadjah Mada University Press, 2004, p. 18.

34 Shiva, Earth Democracy: Justice, Sustainability, and Peace, Cambridge: South End Press, 2005, p. 8. 
benefits (due to obtaining permits and benefit more from the use of natural resources), must bear a greater burden in restoring, conserving and maintaining the environment.Women as subjects who are vulnerable to environmental damage need to be compensated proportionally in terms of economic, social, and cultural consequences from changes in the ecosystem.

In the Indonesian context, environmental management is related to legal subjects as executor and guardian of environmental ecosystems. In Article 3 of Law Number 32 Year 2009 concerning Environmental Protection and Management, it is stated that the objectives of environmental protection and management include protecting the territory of the Unitary State of the Republic of Indonesia from environmental pollution and / or damage; guarantee the safety, health and life of humans; ensure the survival of living things and the preservation of ecosystems; as well as preserving environmental functions.

To realize the aforementioned goals, the role and support of the community, including women, is needed. The social community will provide support when a sense of justice is fulfilled and when the social division is balanced. In order to fulfill justice, it cannot be separated from the role played by the government as an authorized institution to implement laws and regulations. The government, as the guardian and / or implementer of laws on environmental protection and management, gives a fair sense of carrying out environmental management when the use of natural resources is carried out. By realizing justice, namely by maintaining a balance between economic growth and an environmentally sound environment, it can uphold legal certainty and can also provide benefits to all parties..$^{35}$

Finally, ecofeminism as part of feminism is thought that seeks to ensure that women get justice as the main goal of the law itself and ensure that the principle of equality before the law actually applies

35 Sagama, "Analisis Konsep Keadilan, Kepastian Hukum dan Kemanfaatan dalam Pengelolaan Lingkungan" (Analysis on the Concept of Justice, Legal Certainty and Legal Expediency in Environmental Management), Mazahib: Jurnal Pemikiran Hukum Islam, Vol. XV, No. 1, p. 38. 
without any obstacles that come from gender discrimination. ${ }^{36}$

\section{Conclusion}

Ecofeminism as a thought that criticizes the dominance of patriarchy over control of environmental management has encouraged environmental protection movements carried out by women in various places and various countries. From a legal perspective, ecofeminism is an effort for women to get justice as the main goal of law and ensure the principle of equality before the law in managing, protecting and enjoying the benefits of environmental sustainability.

\section{Bibliography}

\section{Books}

Arivia, G., Filsafat Berperspektif Feminis (Feminist-Perspective Philosophy), Jakarta: Yayasan Jurnal Perempuan, 2003.

Bourdieu, P., Dominasi Maskulin (Masculinity Dominance), Yogyakarta: Jalasutra, 2010.

Cuomo, C.J., Feminism and Ecological Communities: An Ethic of Flourishing, New York: Routledge, 1998.

Iskandar, J., Ekologi Manusia dan Pembangunan Berkelanjutan (Human Ecology and Sustainable Development), Bandung: Program Studi Magister Ilmu Lingkungan Universitas Padjajaran, 2009.

Rahman, A.A. et al. (eds.)., Environment and Development in Bangladesh, Dhaka: University Press Ltd., 1994.

Sale, K., Revolusi Hijau: Sebuah Tinjauan Historis-Kritis Gerakan Lingkungan Hidup di Amerika Serikat (Green Revolution: A HistoricalCritical View on Environmental Movement in United States), Jakarta: Yayasan Obor Indonesia, 1996.

Shiva, V., Earth Democracy: Justice, Sustainability, and Peace, Cambridge: South End Press, 2005.

Shiva, V., Mies, M., Ecofeminism: Perspektif Gerakan Perempuan dan

36 Bangun, "Hak Perempuan dan Kesetaraan Gender dalam Perspektif Filsafat Hukum" (The Rights of Women and Gender Equality in the Perspective of Legal Philosophy), Pandecta, Vol. 15, No. 1, p. 81. 
Lingkungan (Ecofeminism: the Perspective of Women and Encironmental Movement), Yogyakarta: IRE Press, 2005.

Slamet, J.S., Kesehatan Lingkungan (Environmental Health), Yogyakarta: Gadjah Mada University Press, 2004.

Soekarno, Sarinah, Jakarta: Jajasan Pembangunan Djakarta, 1951.

Susilo, R.D., Sosiologi Lingkungan (Environmental Sociology), Jakarta: Raja GrafindoPersada, 2008.

Tong, R.P., Feminist Thought, Yogyakarta: Jalasutra, 2010.

\section{Journals}

Astuti, T.M.P., "Ekofeminisme dan Peran Perempuan dalam Lingkungan" (Ecofeminism and the Role of Women in Environment), Indonesian Journal of Conservation, Vol. 1, No. 1, 2012.

Bangun, "Hak Perempuan dan Kesetaraan Gender dalam Perspektif Filsafat Hukum" (The Rights of Women and Gender Equality in the Perspective of Legal Philosophy), Pandecta, Vol. 15, No. $1,2020$.

Dalupe, B., "Dari Hutan ke Politik: Studi Terhadap Ekofeminisme Aleta Baun di Mollo-NTT" (From Forest to Politic: Study on Aleta Baun's Ecofeminism in Mollo-East Nusa Tenggara). Jurnal Polinter, Vol. 5, No. 2, 2020.

Fatimah, S., "Ekofeminisme: Teori dan Gerakan" (Ecofeminism: Theory and Movement). Jurnal Komunikasi dan Penyiaran Islam, Vol. 1, No. 1, 2017.

Maulana, R., Supriatna, N., "Ekofeminisme: Perempuan, Alam, Perlawanan Atas Kuasa Patriarkhi dan Pembangunan Dunia (Wangari Maathai dan Green Belt Movement 1990-2004)" (Ecofeminism: Women, Nature, the Resistance towards Patriarchal Power and World Development). Factum, Vol. 8, No. 2, 2019.

Sagama, S., "Analisis Konsep Keadilan, Kepastian Hukum dan Kemanfaatan dalam Pengelolaan Lingkungan" (Analysis on the Cocept of Justice, Legal Certainty and Legal Expediency in Environmental Management), Mazahib: Jurnal Pemikiran Hukum Islam. Vol. XV, No. 1, 2016.

Scott, K., "Peace Profile: Wangari Maathai and the Green Belt Move- 
ment", Peace Review: A Journal of Social Justice, Vol. 25, No. 2, 2013.

Suliantoro, B.W., "Rekonstruksi Pemikiran Etika Lingkungan Ekofeminisme Sebagai Fondasi Pengelolaan Hutan Lestari” (The Reconstruction on the Thinking of Ecofeminism Environemntal Ethic as the Foundation of Sustainable Forest Management). Jurnal Bumi Lestari. Vol. 11, No. 1. 2011. 111-119.

Wulan, T.R. "Ekofeminisme Tranformatif: Alternatif Kritis Mendekonstruksi Relasi Perempuan dan Lingkungan” (Transformative Ecofeminism: Critical Alternative in Deconstructing the Relation of Woman and Environment). Soladity: Jurnal Transdisiplin Sosiologi, Komunikasi, dan Ekologi Manusia.Vol. 1, No. 1, 2007.

\section{Websites}

Gina, A., 2017, Ekofeminisme: Menyoal Perempuan dan Alam (Ecofeminism: Questioning Women and Nature), https: / /www.jurnalperempuan.org/blog/ekofeminisme-menyoal-perempuan-danalam, accesed in August 16, 2020.

Organisation for Economic Co-operation and Development (OECD), 2008, Gender and Sustainable Development: Maximising The Economic, Social and Environment Role of Women, https: / www.oecd. org/social/ 40881538.pdf, accesed in August 12, 2020.

Ritchie, H., Roger, M., 2019, Gender Ratio, https: / / ourworldindata. org/gender-ratio\#what-share-of-the-population-is-male-andfemale, accesed in August 12, 2020.

Zega, D.C., Putri, L.G.S., 2014, Relasi Alam dan Perempuan dalam Pemikiran Ekofeminisme Vandana Shiva (The Relation of Nature and Women in the Thingking of Vandana Shiva on Ecofeminism), http: / / lib.ui.ac.id/naskahringkas / 2016-05 / S57107-Devi\%20 Christiani\%20Zega, accesed in August 16, 2020. 